\title{
Optimizing CO Reductions in a Diesel Oxidation Catalyst under Diesel Dual Fuel Exhaust Conditions
}

\author{
Tul Suthiprasert ${ }^{\mathrm{a}}$, Tanes Limpurimongkol ${ }^{\mathrm{b}}$, Sirichai Jirawongnuson ${ }^{\mathrm{c}}$, \\ Tanet Aroonsrisopon ${ }^{\mathrm{d}}$, Ekathai Wirojsakunchaie,*
}

Department of Mechanical Engineering, Faculty of Engineering, Kasetsart University, Bangkok, Thailand E-mail, amangdoo34@hotmail.com, btanes.lim@gmail.com, csirichaiam@hotmail.com, dtanet.a@ku.ac.th, .efengeka@ku.ac.th (Corresponding author)

\begin{abstract}
A Diesel Dual Fuel (DDF) engine is an adapted diesel engine that uses natural gas and diesel fuel as the energy source at the same time. Natural gas is mixed with air at the intake manifold while diesel fuel is injected into the combustion chamber directly to initiate the combustion process. Based on the past DDF literatures, they are indicated that Carbon Monoxide (CO) emissions were more substantial at low load conditions than those when running in diesel engine modes. The Diesel Oxidation Catalyst (DOC) that is installed to this diesel engine is, therefore, not capable to reduce $\mathrm{CO}$ emissions abide by to the emission regulation. Literatures also indicate that the exhaust temperature, mass flow rate, Oxygen $\left(\mathrm{O}_{2}\right)$ concentration, CO concentration, as well as Propane $\left(\mathrm{C}_{3} \mathrm{H}_{8}\right)$ concentration may affect $\mathrm{CO}$ conversion efficiency of the catalytic converter. In the present work, Design of Experiments (DOE) is employed to explore the behavior of various factors that affect $\mathrm{CO}$ reductions in the catalytic converter. Once the knowledge is founded, the optimization of CO reductions in the catalytic converter at $90 \%$ is studied extensively.

Using Fractional Factorial Design for screening factors on CO conversions, it is found that the exhaust temperature, mass flow rate, $\mathrm{O}_{2}$ concentration, and $\mathrm{CO}$ concentration affect $\mathrm{CO}$ conversions of the catalytic converter significantly. Optimization of these factors, by using Box-Behnken Design, for reducing $\mathrm{CO}$ concentration of $6200 \mathrm{ppm}$ which is the maximum CO amount emitted from the tested engine shows that $90 \%$ of $\mathrm{CO}$ conversion can be reached at the exhaust temperature of $200^{\circ} \mathrm{C}$, the mass flow rate of 25 $\mathrm{kg} / \mathrm{h}$, and the oxygen concentration of $16 \%$.
\end{abstract}

Keywords: Diesel dual fuel, diesel oxidation catalyst, CO emissions, design of experiment.

ENGINEERING JOURNAL Volume 21 Issue 5

Received 29 January 2017

Accepted 22 April 2017

Published 29 September 2017

Online at http://www.engj.org/

DOI:10.4186/ej.2017.21.5.93 


\section{Introduction}

A DDF engine is a modified diesel engine that mixes natural gas with air before entering the combustion chamber. The diesel injector injects diesel fuel to ignite the mixer [1]. This technique help decreasing the quantity of diesel fuel usage with slight modification on the engine. In addition, it also decreases NOx and soot emissions because of lower combustion temperature and less amount of diesel fuel [2]. However, CO and THC concentrations in the exhaust of this adapted engine are higher than those of the conventional engine [3], [4].

From literature review, there are many parameters that affect $\mathrm{CO}$ conversion efficiency for Pt-Pd diesel oxidation catalyst (DOC) [5]. High $\mathrm{O}_{2}$ concentration will increase the efficiency, while high $\mathrm{CO}$ concentration will decrease the efficiency [6]. At higher exhaust temperature, pre-CAT temperature, CO will decrease with better efficiency [7]. And lastly, the exhaust flow rate in which lower flow rate leads better efficiency.

With many parameters for CO-reduction, therefore, this research is done by using Design of Experiment (DOE) concept to find the proper condition for improving CO reduction efficiency. This technique is employed to help analyzing the relationships and interaction among each factors [8]. Many researches in aftertreatment applications have implemented DOE for system optimization [9], [10], [11]. However, none of these is employed for studying relationships among exhaust environments on catalyst performance. For this research study, the Fractional factorial design is first used to screen factors that have no or little effects to $\mathrm{CO}$ conversion efficiency. This design also help reducing the numbers of the experiment due to the limited time and resources. After the parameters that are influenced CO conversion efficiency are reduced, the Box-Behnken design is chosen for studying 3-level factors effect. This design is one of the response surface methods that is very useful to find the quadratic relationship among factors.

\section{Simulation and Experimental Setup}

In the current study, the research methodology is focused on simulation approach. This is due to the fact that the ultimate goal is to optimize proper conditions for $\mathrm{CO}$ reductions which if done by experiments, it will be time consuming process and yield high operating costs. Modeling DOC can be found in many past literatures in both 1-D and 3-D [12], [13], [14]. Once calibrated with the experimental data, the model can be used to benchmark and optimize the design which is favorable for time and cost reduction before implementing to the real engine and exhaust setup.

\subsection{DOC Model}

The model of the DOC was built on a computer program, called AVL-BOOST. This software package is employed to simulate flows in the engine model and its components. The flow model for each component involves simultaneous solutions of the continuity, momentum, energy, and specie equations. These equations are solved in one-dimensional (1-D), which means that all quantities are averages across the flow direction. The model can be viewed as a series of many discretized volume where each flow model is represented by a single volume and every pipe is divided into one or more volumes. DOC model can be viewed as a series of tube bundles representing catalyst brick. Figure 1 shows a DOC model in AVLBOOST where ATB1 is the inlet boundary condition, ATB2 is the outlet boundary condition, and CAT1 is the DOC model.

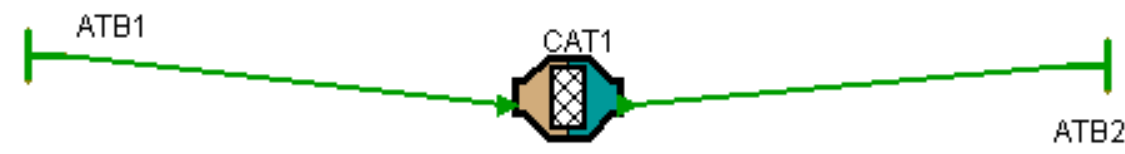

Fig. 1. DOC model in AVL-BOOST. 


\subsection{Chemical Kinetic Parameters}

The DOC is composed of catalyst that accelerated the reaction between exhaust gas and DOC. The reaction equation can be expressed by employing the surface mechanisms called Langmuir Hinshelwood [14], [15], [16]. The kinetic model of $\mathrm{CO}$ and $\mathrm{C}_{3} \mathrm{H}_{8}$ can be described as follows.

$$
\begin{gathered}
\dot{r}=\frac{\left[K_{1} \cdot e^{\left(\frac{-E_{1}}{T_{S}}\right)} \cdot y_{C O} \cdot y_{O_{2}}\right] \cdot\left[1+K_{2} \cdot e^{\left(\frac{-E_{2}}{T_{S}}\right)} \cdot y_{C O}+K_{3} \cdot e^{\left(\frac{-E_{3}}{T_{S}}\right)} \cdot y_{C_{3} H_{6}}\right]^{-2}}{\left[1+K_{4} \cdot e^{\left(\frac{-E_{4}}{T_{S}}\right)} \cdot y_{C O}^{2} \cdot y_{C_{3} H_{6}}^{2}\right] \cdot\left[1+K_{5} \cdot e^{\left(\frac{-E_{5}}{T_{S}}\right)} \cdot y_{N O}^{0.7}\right] \cdot T_{S}} \\
\dot{r}=\frac{\left[K_{1} \cdot e^{\left(\frac{-E_{1}}{T_{S}}\right)} \cdot y_{C_{3} H_{8} \cdot y_{O_{2}}}\right] \cdot\left[1+K_{2} \cdot e^{\left(\frac{-E_{2}}{T_{S}}\right)} \cdot y_{C O}+K_{3} \cdot e^{\left(\frac{-E_{3}}{T_{S}}\right)} \cdot y_{C_{3} H_{6}}\right]^{-2}}{\left[1+K_{4} \cdot e^{\left(\frac{-E_{4}}{T_{S}}\right)} \cdot y_{C O}^{2} \cdot y_{C_{3} H_{6}}^{2}\right] \cdot\left[1+K_{5} \cdot e^{\left(\frac{-E_{5}}{T_{S}}\right)} \cdot y_{N O}^{0.7}\right] \cdot T_{S}}
\end{gathered}
$$

where $\mathrm{r}=$ Reaction Rate $\left(\mathrm{kmol} / \mathrm{m}^{\wedge} 3 \mathrm{~s}\right), \mathrm{K}=$ Term in reaction rate equation (variable), $\mathrm{E}=$ Activation temperature of each reaction $(\mathrm{K}), \mathrm{T}=$ Temperature of solid $(\mathrm{K})$, and $\mathrm{y}=$ Mole fraction of species $(-)$

\subsection{Simulated Exhaust Gas}

AVL-BOOST model is calibrated and compared to the experimental data. The experiment is done on the synthetic exhaust gas generating system as shown in Fig. 2. The system is designed to control temperature, gas concentrations, and exhaust flow rates separately. Therefore, the system can generate various exhaust characteristics that DOC experiences while FTIR is used to measure emission species. More details of this setup can be found in [17], [18].

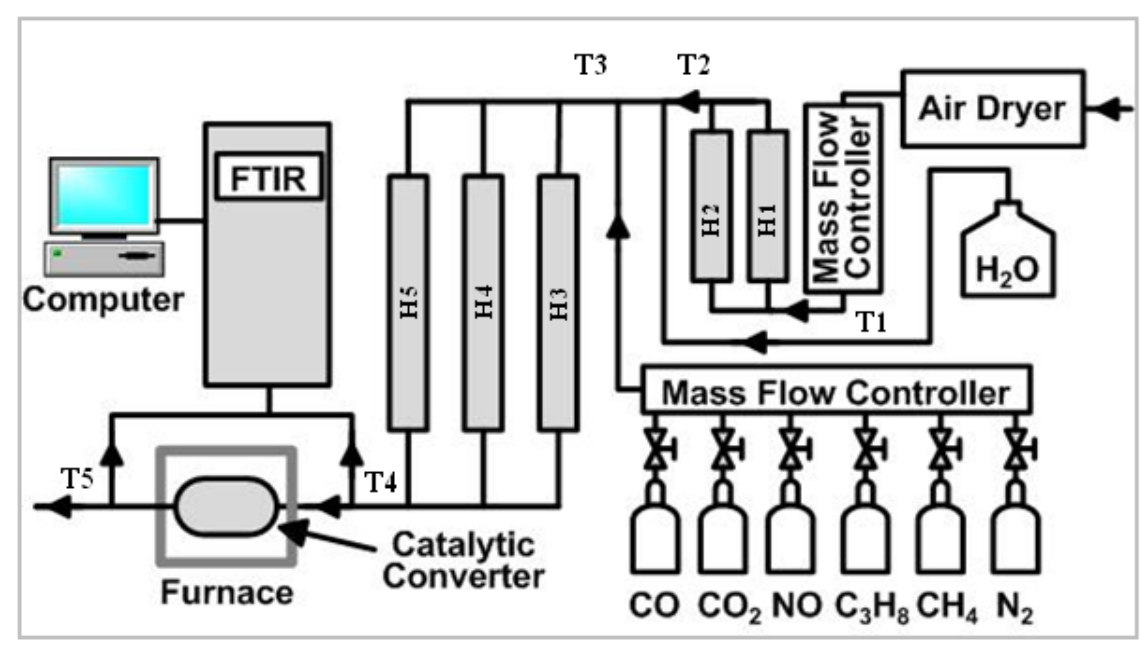

Fig. 2. Synthetic exhaust gas generating system.

Since exhaust gas compositions depends tremendously upon each engine operating conditions, the catalyst efficiency changes significantly during a cycle driving test. In this work, the acceleration phase in the city cycle is selected as an exhaust representative that the catalyst experiences. This is due to the fact that $\mathrm{CO}$ emissions from DDF combustion during the acceleration phase is relatively high in the city cycle as shown in Fig. 3. [19]. 


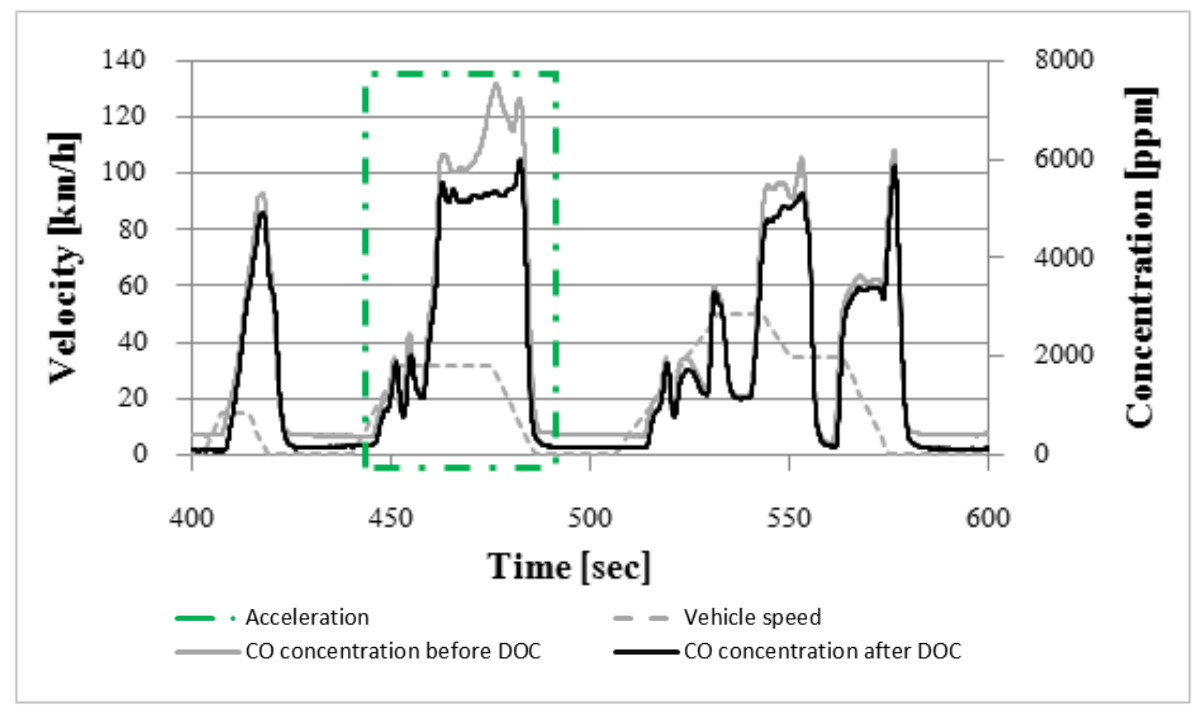

Fig. 3. CO Emissions during new european driving cycle (NEDC) test.

DOE factors for the simulation were referenced from the DDF experimental result as shown in Table 1. The low/high levels are indicated based on the $\mathrm{min} / \mathrm{max}$ values of measurable parameters from Fig. 3. In this simulation, $\mathrm{C}_{3} \mathrm{H}_{8}$ is used as a representative of Non Methane Hydrocarbon (NMHC). There is a tremendous high concentration of Methane $\left(\mathrm{CH}_{4}\right)$ emissions in the exhaust, but in this work, however, $\mathrm{CH}_{4}$ is excluded from the analysis. DOE of $\mathrm{CH}_{4}$ emissions will be studied in the next phase of this research study.

Table 1. Parameters for DOE.

\begin{tabular}{|l|l|l|l|}
\hline Factor & Unit & Low level (-1) & High level (+1) \\
\hline Flow Rate (A) & $\frac{k g}{h}$ & 24 & 93 \\
\hline Temperature (B) & ${ }^{\circ} \mathrm{C}$ & 122 & 173 \\
\hline $\mathrm{O}_{2}(\mathrm{C})$ & $\%$ & 8 & 17 \\
\hline $\mathrm{CO}(\mathrm{D})$ & $\mathrm{ppm}$ & 530 & 5780 \\
\hline $\mathrm{C}_{3} \mathrm{H}_{8}(\mathrm{E})$ & $\mathrm{ppm}$ & 1567 & 7533 \\
\hline
\end{tabular}

\subsection{DOC Physical Properties}

The properties of the DOC can be seen in Table 2. Note that this DOC is manufactured specifically to meet EURO IV emission standard for a natural gas vehicle [20] and it is not an Original Equipment Manufacturer (OEM) part. Definitions of each DOC parameters in Table 2 can be found in [21].

Table 2. Tested DOC properties.

\begin{tabular}{|l|l|}
\hline Parameter & Tested DOC \\
\hline Cell Per Square Inch $(\mathrm{CPSI})$ & 300 \\
\hline Cell Shape & Square \\
\hline Volume $(\mathrm{L})$ & 3.4 \\
\hline PGM Loading $\left(\mathrm{g} / \mathrm{ft}^{3}\right)$ & 210 \\
\hline Mass ratio of $\mathrm{Pt}: \mathrm{Pd}$ & $1: 5$ \\
\hline Washcoat & $\mathrm{Al}_{2} \mathrm{O}_{3}$ \\
\hline
\end{tabular}




\section{Results from Simulation}

\subsection{Comparing Results from Simulation and Light-off Temperature Experiment}

In the first step, the kinetic model of DOC as seen in Eq. (1) is calibrated comparing to the $\mathrm{CO}$ and $\mathrm{C}_{3} \mathrm{H}_{8}$ Light-off Temperature experiments individually. $1000 \mathrm{ppm}$ of CO and $\mathrm{C}_{3} \mathrm{H}_{8}$ is fed into DOC which lies in the furnace at the rate of 10 liter/min (space velocity $176.47 \mathrm{hr}^{-1}$ ) sufficient for emission analyzer flow requirement. Since the goal is to find proper kinetic parameters for $\mathrm{CO}$ in this model, thus, only $\mathrm{K}_{1}$ and $\mathrm{E}_{1}$ for $\mathrm{CO}$ and $\mathrm{C}_{3} \mathrm{H}_{8}$ are tuned based on the experimental data due to temperature ranges for active site on catalyst. It is found out that $\mathrm{K}_{1}\left(\mathrm{kmol} . \mathrm{K} / \mathrm{m}^{2} . \mathrm{s}\right)$ and $\mathrm{E}_{1}\left({ }^{\circ} \mathrm{C}\right)$ are $12.7 \times 10^{7}$ and $8 \times 10^{3}$, respectively, for CO and $55 \times 10^{7}$ and $12.2 \times 10^{3}$, respectively, for $\mathrm{C}_{3} \mathrm{H}_{8}$, which correspond to values found in the literature [6]. The rest of kinetic parameters are employed using default values recommended in AVL-BOOST user manual.

An example of $\mathrm{CO}$ light-off temperature experiment is shown in Fig. 4. Experimental data below $100^{\circ} \mathrm{C}$ is closed to the noise of the emission analyzer and is not considered during tuning process. Slope of the simulation curve matches well with the experimental data.

The temperature for $100 \%$ CO conversion can range from 135 to $280{ }^{\circ} \mathrm{C}$ depending on the catalyst of the DOC [22, 23].

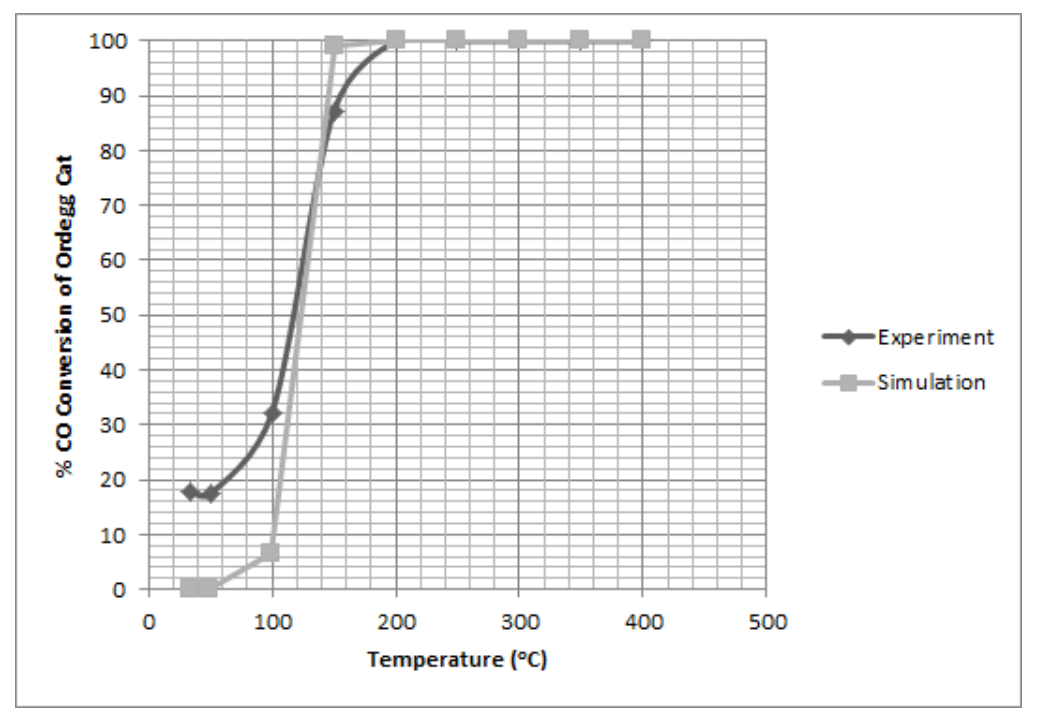

Fig. 4. CO light-off temperature experiment comparing to simulation.

\subsection{Results from Design of Experiment}

\subsubsection{Fractional factorial design}

Once the model is calibrated, DOE is performed by using Design Expert, a software package for DOE analysis. Fractional factorial design is firstly used for designing the current DOE in order to filtering factors that mostly impact CO conversion efficiency. In addition, this DOE methodology is selected to help reducing the number of experiments. Figure 5 shows a normal probability plot output from Design Expert. If any points are significantly deviated from the straight line, it means that those factors have large effects on the response. 


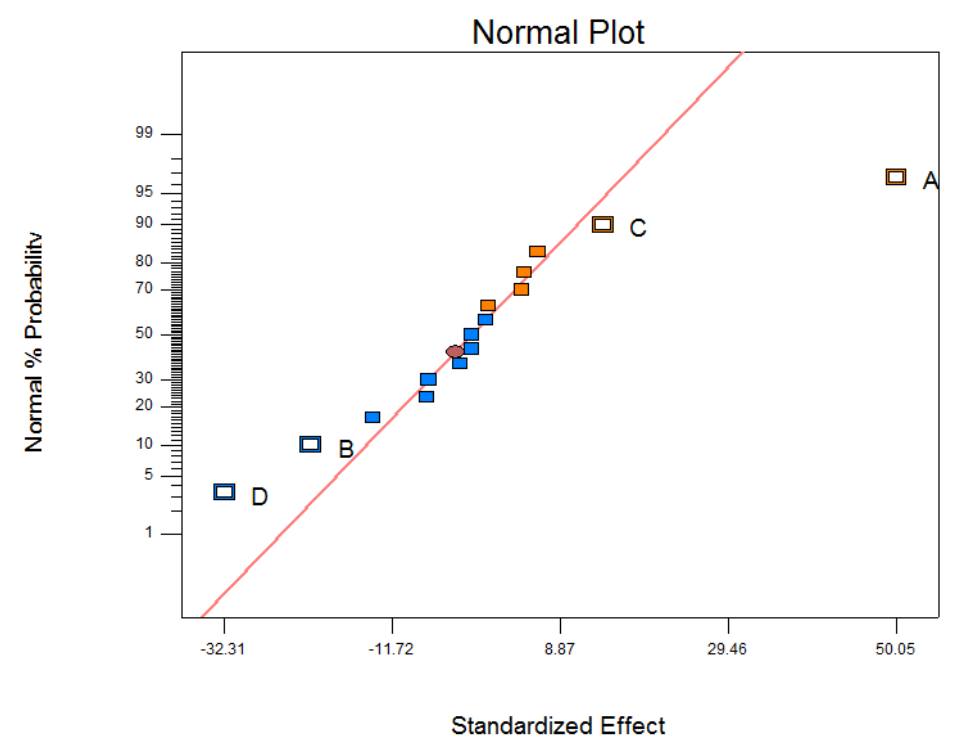

Fig. 5. Normal probability plot between factors and response.

Figure 5 indicates that Factors A, B, C, and D significantly impact CO conversion efficiency. In order to show more details of these, Figs. 6 to 9 are constructed. Figures 6 to 9 have shown individual effect plots of each factors on CO conversion efficiency. In general, within the range of tested DOE parameters, increasing temperature from 122 to $173^{\circ} \mathrm{C}$ will largely increase CO conversion efficiency from $20 \%$ to $70 \%$. Increasing $\mathrm{O}_{2}$ concentration from $8 \%$ to $17 \%$ will slightly increase $\mathrm{CO}$ conversion efficiency from $25 \%$ up to $45 \%$. On the contrary, increasing CO concentration from $530 \mathrm{ppm}$ to $5780 \mathrm{ppm}$ and flow rate from 24 $\mathrm{kg} / \mathrm{hr}$ to $93 \mathrm{~kg} / \mathrm{hr}$ will decrease CO conversion efficiency from $50 \%$ to $25 \%$. Trends from these experiments are found to be consistent to the literature found in [5], [7], and [12].

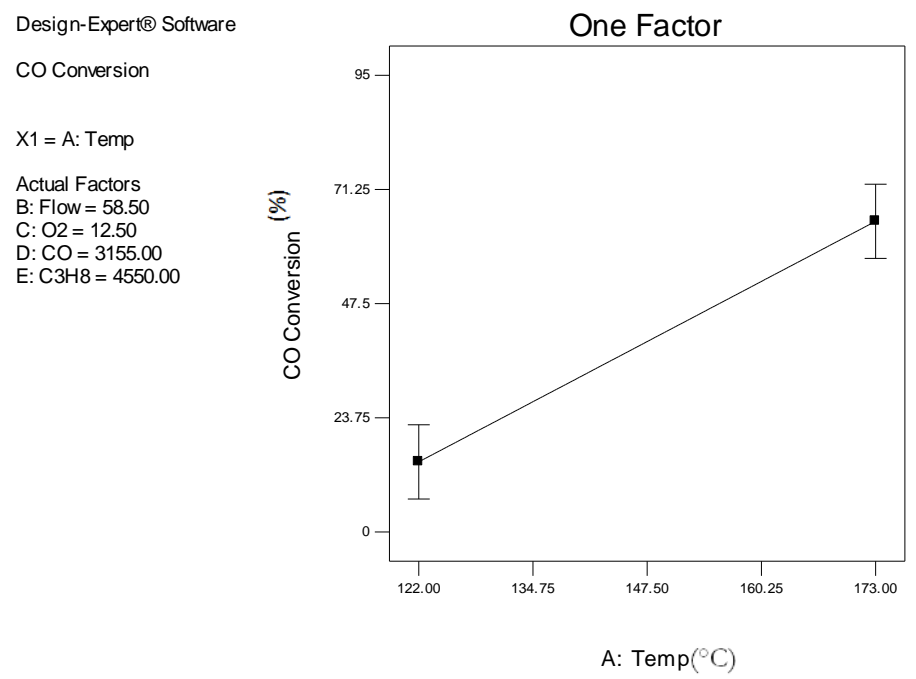

Fig. 6. Effects of Temp. (Factor A) on CO conversion efficiency. 


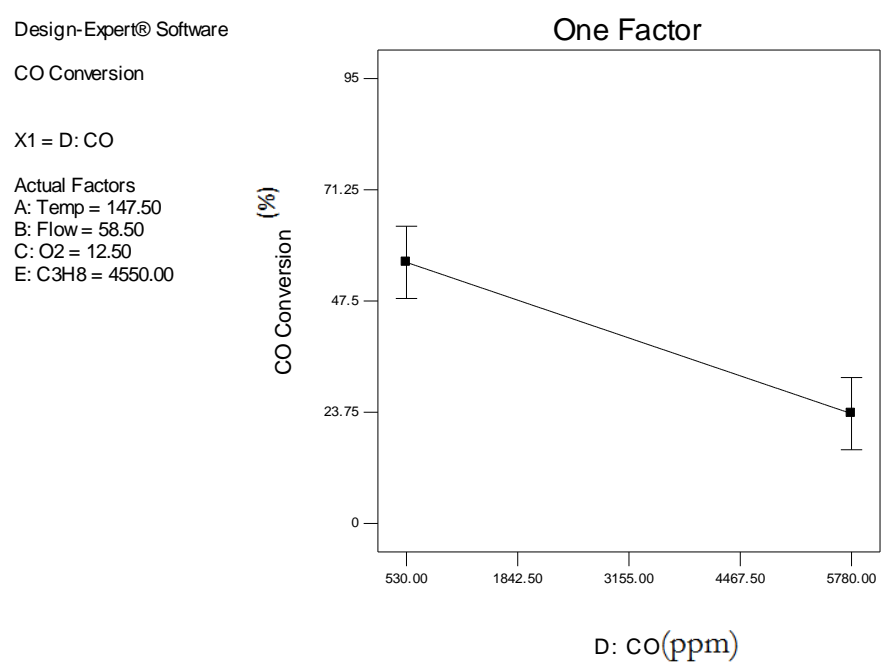

Fig. 7. Effects of CO concentration (Factor D) on CO conversion efficiency.

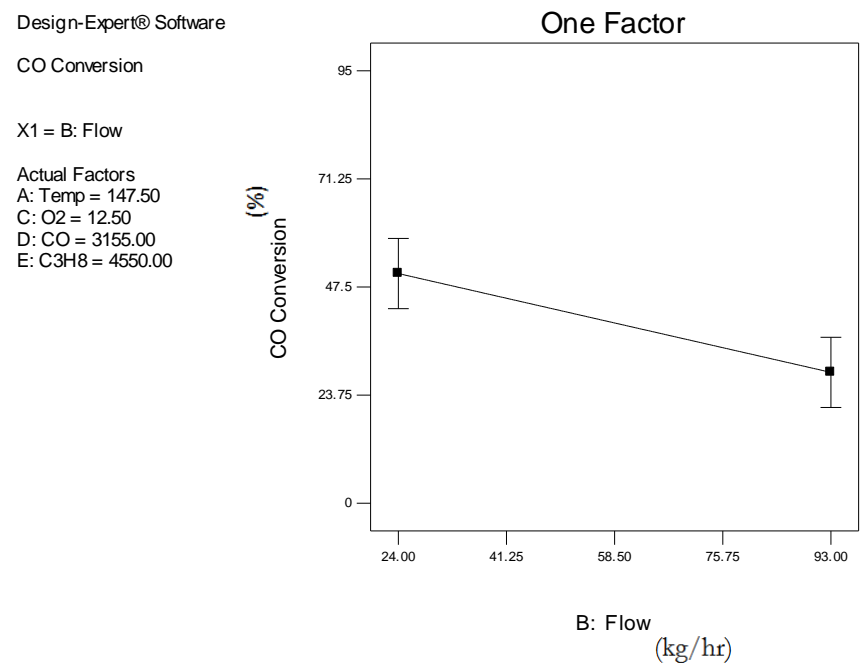

Fig. 8. Effects of exhaust flow rate (Factor B) on CO conversion efficiency.

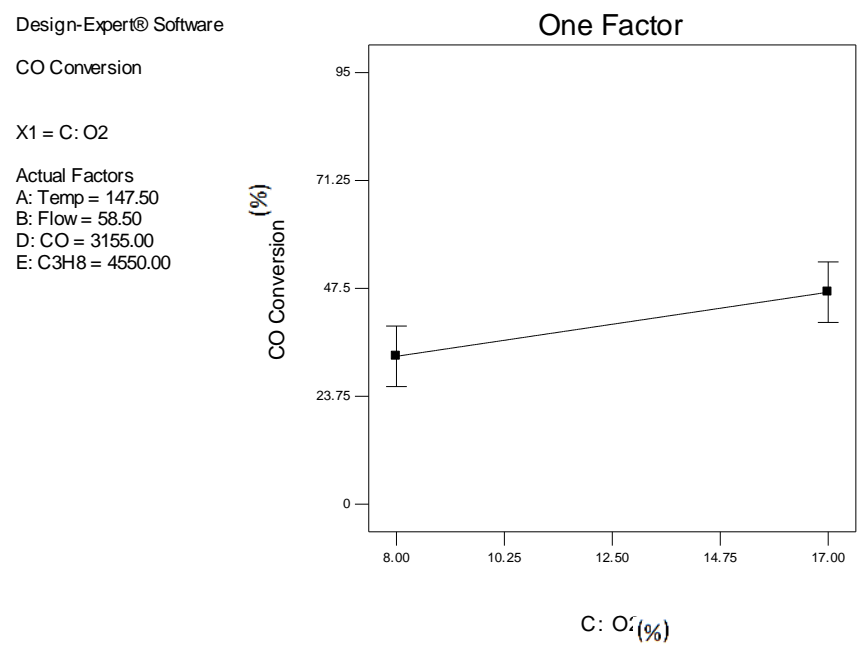

Fig. 9. Effects of $\mathrm{O}_{2}$ Concentration (Factor C) on CO Conversion Efficiency 
Results from above figures have shown that these 4 factors - exhaust temperature, exhaust flow rate, $\mathrm{CO}$ and $\mathrm{O}_{2}$ concentration affect $\mathrm{CO}$ conversion efficiency. In the next step, these 4 factors were then analyzed to yield a proper condition for reducing CO. As for $\mathrm{C}_{3} \mathrm{H}_{8}$ (Factor E), it provides no effect on CO conversion efficiency. This is due to the fact that the range of temperature on DOE is too low for DOC to oxidize $\mathrm{C}_{3} \mathrm{H}_{8}$. Therefore, the amount of $\mathrm{C}_{3} \mathrm{H}_{8}$ concentration remains the same.

\subsubsection{Box-Behnken design}

The four factors Box-Behnken design is implemented to find proper conditions of reducing CO [17]. Table 3 shows ranges of each parameters for optimizing $\mathrm{CO}$ conversion efficiency.

Table 3. Parameters for optimizing CO conversion efficiency.

\begin{tabular}{|l|l|l|l|}
\hline Factor & Unit & Low level (-1) & High level (+1) \\
\hline Flow Rate (A) & $\mathrm{kg} / \mathrm{hr}$ & 125 & 200 \\
\hline Temperature (B) & ${ }^{\circ} \mathrm{C}$ & 25 & 96 \\
\hline $\mathrm{O}_{2}(\mathrm{C})$ & $\%$ & 8 & 16 \\
\hline $\mathrm{CO}(\mathrm{D})$ & $\mathrm{ppm}$ & 100 & 6200 \\
\hline
\end{tabular}

These factors are then simulated to get results by using Design Expert. However, before analyzing these results, the correctness must be checked. By plotting the normal probability plot, it shows that the plot is linear, as seen in Fig. 10 which is similar to the Fractional factorial design shown in Fig. 5. This indicates that the data can be used for further analysis.

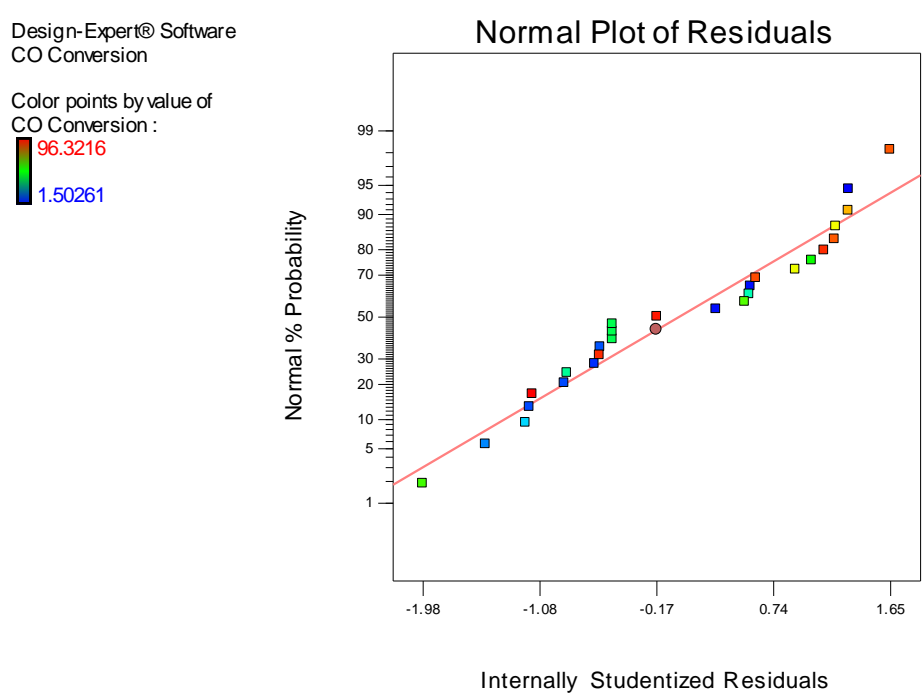

Fig. 10. Normal probability plot on Box-Behnken design.

The result was then analyzed to create the regression model that helps predicting CO conversion efficiency. Table 4 shows the regression analysis based on Box-Behnken design. From Table 4, the model can be created as "CO Conversion $(\%)=47.80+41.55 \mathrm{~A}-9.89 \mathrm{~B}+6.83 \mathrm{C}-19.74 \mathrm{D}$ ". This come with " $\mathrm{R}$ sq of 0.8643 ". This value indicates that there is $86.43 \%$ to correctly predict CO conversion efficiency based on this analysis. 
Table 4. Regression analysis based on Box-Behnken DESIGN.

\begin{tabular}{|l|l|l|l|}
\hline Source & Sum of Square & Mean of Square & P value \\
\hline Model & 27126.3 & 6781.60 & $<0.0001$ \\
\hline A-Temp & 20717.2 & 20717.26 & $<0.0001$ \\
\hline B-Flow & 1173.6 & 1173.66 & 0.0128 \\
\hline C-O2 & 559.00 & 559.00 & 0.0749 \\
\hline D-CO & 4676.478 & 4676.47 & $<0.0001$ \\
\hline
\end{tabular}

Figure 11 demonstrates an example of outputs from Design Expert for CO conversion optimization. At low-load engine conditions, it is found out that to reach CO conversion efficiency more than $90 \%$ at $\mathrm{CO}$ concentration of $6200 \mathrm{ppm}$, the exhaust temperature, the exhaust flow rate, and $\mathrm{O}_{2}$ concentration must reach $200^{\circ} \mathrm{C}, 16 \%$, and $25 \mathrm{~kg} / \mathrm{h}$, respectively.
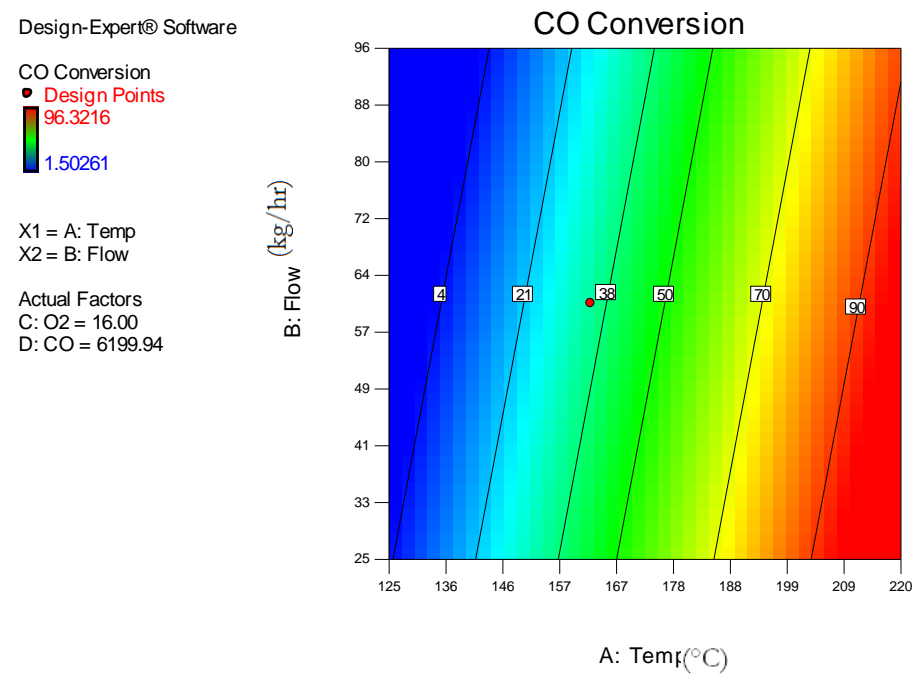

Fig. 11. Proper conditions of 90\% CO conversion efficiency for CO concentration of $6200 \mathrm{ppm}$.

\section{Conclusions}

This research uses DOE concept to study CO reductions in a DOC model in order to determine factors that affect $\mathrm{CO}$ conversion efficiency during low load conditions of DDF exhaust-like conditions. The model is then implemented to determine proper conditions for CO conversion efficiency at $90 \%$. Results shows that exhaust flow rate (A), exhaust temperature (B), $\mathrm{O}_{2}$ concentration $(\mathrm{C})$, and $\mathrm{CO}$ concentration (D) are major factors that influence $\mathrm{CO}$ conversion efficiency. Low exhaust flow rate, high exhaust temperature, high $\mathrm{O}_{2}$ concentration, and low $\mathrm{CO}$ concentration can help increase $\mathrm{CO}$ conversion efficiency. At a significance of 0.05 , the relationship between factors and response can fit into the regression model as "CO Conversion $(\%)=47.80+41.55 \mathrm{~A}-9.89 \mathrm{~B}+6.83 \mathrm{C}-19.74 \mathrm{D}$ ". This model can correctly predict up to R-square of $86 \%$. For reaching $90 \%$ CO conversion efficiency and with CO concentration of $6200 \mathrm{ppm}$ at low load conditions, the exhaust temperature should be at $200^{\circ} \mathrm{C}$, with the flow rate of $25 \mathrm{~kg} / \mathrm{h}$, and $\mathrm{O}_{2}$ concentration of $16 \%$.

\section{Acknowledgement}

The author would like to express sincere thanks to The Graduate School, Kasetsart University for being a financial sponsor of this project. A special thanks also goes to PTT Research and Technology Institute for providing experimental results. This work is also financially supported by The Thailand Research Fund (TRF) via Research and Researcher for Industry (RRi) Contract No. PHD56I0049. 


\section{Nomenclature}

$\begin{array}{llll}\mathrm{C}_{3} \mathrm{H}_{8} & \text { Propane } & \text { FTIR } & \text { Fourier Transform Infrared Spectroscopy } \\ \mathrm{CH}_{4} & \text { Methane } & \text { K } & \text { Pre-exponential factor0 } \\ \mathrm{CO} & \text { Carbon Monoxide } & \text { NEDC } & \text { New European Driving Cycle } \\ \mathrm{CO}_{2} & \text { Carbon Dioxide } & \text { NMHC } & \text { Non Methane Hydrocarbon } \\ \mathrm{CPSI} & \text { Cell per Square Inch } & \text { OEM } & \text { Original Equipment Manufacturer } \\ \text { DDF } & \text { Diesel Dual Fuel } & \text { PGM } & \text { Platinum Group Metal } \\ \text { DOC } & \text { Diesel Oxidation Catalyst } & \mathrm{r} & \text { Reaction rate } \\ \text { DOE } & \text { Design of Experiment } & \text { THC } & \text { Thermal hydrocarbon } \\ \text { E } & \text { Activation temperature }(\mathrm{K}) & \text { y } & \text { Mole fraction of species }\end{array}$

\section{Reference}

[1] D. T. Hountalas and R. G. Papagiannakis, "Combustion and exhaust emission characteristics of a dual 1998. fuel compression ignition engine operated with pilot Diesel fuel and natural gas," Energy Conversion and Management, vol. 45, pp. 2971-2987, 2004.

[2] K. Wannatong, N. Akarapanyavit, S. Siengsanorh, T. Aroonsrisopon, and S. Chanchaona, "New diesel dual fuel concepts, part load improvement," SAE Technical Paper, 2009-01-1797, 2009.

[3] J. B. Heywood, Internal Combustion Engine Fundamentals. McGraw-Hill, 1988.

[4] T. Korakianitis, A. M. Namasivayam, and R. J. Crookes, "Natural-gas fueled spark-ignition (SI) and compression-ignition (CI) engine performance and emission," Progress in Energy and Combustion Science, vol. 37, no. 1, pp. 89-112, 2011.

[5] S. Sumiya, H. Oyamada, T. Fujita, K. Nakamura, K. Osumi, and Y. Tashiro,, "Highly robust diesel oxidation catalyst for dual mode combustion system," SAE Technical Paper, 2009-01-0280, 2009.

[6] D. D. Beck, J. W. Sommers, and C. L. DiMaggio, "Axial characterization of oxygen storage capacity in close-coupled lightoff and underfloor catalytic converters and impact of sulfur," Applied Catalysis B. Environmental, vol. 11, pp. 273-290, 1997.

[7] O. Lepreux, Y. Creff, and N. Petit, "Model based temperature control of a diesel oxidation catalyst," Journal of Process Control, vol. 22, pp. 41-50, 2012.

[8] D. C. Montgomery, Design and Analysis of Experiments. John Wiley and Sons, Inc., 2009.

[9] D. Arrowsmith, A. Bott, and P. Bush, "Development of a compact Urea-SCR+CRT system for heavyduty diesel using a design of experiments approach," SAE Technical Paper, 2006-01-0636, 2006.

[10] K. D. Deeng, A. R. Mohamed, and S. Bhatia, "Process optimization studies of structured Cu-ZSM-5 zeolite catalyst for the removal of NO using design of experiments (DOE)," Chemical Engineering Journal, vol. 103, pp. 147-157, 2004.

[11] J. Sjoblom, K. Papadakis, and D. Creaser, "Use of experimental design in development of a catalyst system," Catalysis Today, vol. 100, pp. 243-248, 2005.

[12] J. C. Wurzenberger and B. J. Peters, "Catalytic converters in a 1D cycle simulation code considering 3D behavior," SAE Technical Paper, 2003-01-1002, 2003.

[13] G. C. Koltsakis and A. M. Stamatelos, "Modeling dynamic phenomena in 3-way catalytic converters," Chemical Engineering Science, vol. 54, pp. 4567-4578, 1999.

[14] G. C. Koltsakis, P.A. Konstantinidis, and A. M. Stamatelos, "Development and application range of mathematical models for 3-way catalysts," Applied Catalysis B. Environmental, vol. 12, pp. 161-191, 1997.

[15] S. Yang, A. M. Valiente, M. B. Gonzalez, I. R. Ramos, and A. G. Ruiz, "Methane combustion over supported palladium catalysts I. Reactivity and active phase," Applied Catalysis B. Environmental, vol. 28, pp. 223-233, 2000.

[16] R. Abbasi, L. Wu, S. E. Wanke, and R. E. Hayes, "Kinetics of methane combustion over Pt and Pt-Pd catalysts," Chem. Eng. Res. Des., vol. 90, pp. 1930-1942, 2012.

[17] S. Jirawongnusona, W. Wachirapan, T. Suthiprasert, and E. Wirojsakunchai, "A parametric study of diesel oxidation catalyst performance on CO reductions in diesel dual fuel engine exhaust," Key Engineering Materials, vol. 656-657, pp. 538-543, 2015.

[18] W. Wachirapan, "Parameters that effect diesel oxidation catalyst performance on CO and HC reduction from diesel engines adapted to diesel dual fuel," M.S. thesis, Kasetsart University, 2013. 
[19] T. Aroonsrisopon, M. Salad, E. Wirojsakunchai, K. Wannatong, S. Siangsanorh, and N. Akarapanjavit, "Injection strategies for operational improvement of diesel dual fuel engines under low load conditions," SAE Technical Paper, 2009-01-1855, 2009.

[20] K. Kallinen, M. Härkönen, and M. Pitkänen, “Advanced catalysts for CNG engines," SAE Technical Paper, 2004-28-0028, 2004.

[21] R. M. Heck and J. F. Robert, Catalytic Air Pollution Control Commercial Technology, 2nd ed. Canada: WileyInterscience, 2002.

[22] A. Singhania and M. G. Shipra, "Nanocrystalline Zro2 and Pt-Doped Zro2 catalysts for lowtemperature CO oxidation," Beilstein Journal of Nanotechnology, vol. 8, pp. 264-71, 2017.

[23] S. Kaya and U. Deniz, "CO oxidation over mono and bimetallic sequentially impregnated Pd-Pt catalysts," Turkish Journal of Chemistry, vol. 32, pp. 645-52, 2008. 